\title{
WRITING CULTURE, WRITING LIFE: AN INTERVIEW WITH JAMAICA KINCAID
}

Kerry Johnson

This interview was conducted by phone on February 12, 1996, while Jamaica Kincaid was on tour promoting her 1996 novel,The Autobiography of My Mother. Kincaid is the author of works such as At the Bottom of the River (1983), Annie John (1985), and Lucy (1990), which explore the complex cultural and personal heritages of Caribbean women. A surge in publications by Caribbean women writers such as Kincaid has been accompanied by academic discussion of the political and literary repercussions of colonialism. In this interview I took the opportunity to talk to Kincaid about her work in both its personal and political contexts, and to interrogate the terms "colonial" and "postcolonial" as they apply to both political conditions and the personal creative process of literary production.

In a 1987 interview with Selwyn Cudjoe, you said you took "Jamaica" as your name to symbolize a place to which you would not return. You do return in your fiction, however; not to Jamaica, but to Antigua, and in your new novel, The Autobiography of My Mother, to Dominica. ${ }^{1}$ Why is your imagination continually drawn back to the Caribbean?

My imagination has never left the Caribbean, and in that respect, I have never entirely left. I have gone away physically, and I have returned and left again, but inside myself, it is a place that I have never left. I don't write out of a particular need to return there in writing, because I don't write as a conscious reaction to a need. Writing is a part of who I am. I think about these places in the Caribbean and the events that happened there every day-sometimes every moment, if I am alone. Because this is what I think about, this is what I write about.

Your essays are on topics as diverse as gardening, your home, and politics. ${ }^{2}$ Will you continue writing about the Caribbean, and will that work take on a more political tone? 
I don't look at the future in that way. As long as I'm alive and healthy I will be doing something, but it is hard to say with certainty that I will be writing about a certain topic, or a certain place. I can only know after I have written it, and it is no longer a part of me.

When I write I don't make a great distinction between novels and nonfiction. As for my own reading, I never read fiction anymore. Someone told me that this is very common among fiction writers: when you are in your own world, you don't really want to know the rest of the world. I read history and essays. I read obsessively about gardens because I know so little that I'm always trying to catch up on my knowledge by reading plant hunters' journals and plant catalogs. I just read an architectural study of Italian gardens. Recently I visited a botanical garden in San Francisco. These gardens had areas of plants that were supposed to be from the "Mediterranean" - which would include South Africa, Australia and New Zealand! It was very exciting, because I saw plants I had only read about become real for me before my eyes: proteas, tree asters. The essays I've written about the garden are an evolution in my own thinking. I wrote a piece about my house as part of a contract with The New Yorker. I don't enjoy writing on command, but I wrote that essay as I do everything else - out of my soul. Although the essay was cut for publication, I like the piece. If I were to republish it, I would have it published in its entirety, as it is a much better piece than it appeared as printed in The New Yorker. However, it is not so much representative of my writing as it is of a request by an editor.

You wrote a piece about the elections in Antigua. ${ }^{3}$ How did you generate this piece, and how did people respond to it?

I had planned to write that piece. I was curious about what the Antiguan people would do when given a chance to make a change from the regime of the Bird family. The people did not opt to change. I wrote it for The New Yorker, which turned it down. I eventually published it with Clockwatch Review. Antiguans themselves, however, don't generally read articles such as that one - but I would say that this does not matter. I don't really write for Antiguans. I don't really write for any particular audience, although generally you hope that when you write a political piece such as this one, it will matter to the people you are from. All the writing I've done comes out of my contemplation of the world, my thoughts on what has happened to the groups of people I'm from. I don't think that this is political; I think this is life. The essay on Antigua and A Small Place are not political. ${ }^{4}$ For me, they are life.

The harms of colonialism are evident in your past work and in your new work, The Autobiography of My Mother. In this novel, however, you meld the personal story of the character Xuela explicitly with her history and with her future as a member of a "postcolonial community." In one passage, Xuela seems to reflect on the current political state. She says, "My impulse is to the good, my good is to serve myself. I am not a people, I am not a nation. I only wish from time to time to make my actions be the actions of a people, to make my actions 
be the actions of a nation." Can the actions of an individual, in your opinion, effect real political change?

All the great events that contributed to the conditions of this character's life stemmed from the imaginations of individuals. Active imaginations create events of action. For example, Christopher Columbus was an individual, and his actions provoked great events. Hordes of people followed him, and what was the action of an individual was enlarged by the action of groups of people. The individual, for me, is paramount: the individual imagination acts, the individual speaks, and if people are convinced by what that individual says, they will follow. In that sense, a great event can be set in motion by an individual. In the other direction, however, a certain event can have great effects on an individual. The character in this book is a product of my interest in how an event that was set in motion by one individual would impact and would work itself out in another single person, in one individual. I work from individual to event and back to an individual again - but I return to the individual by a different route.

Is this passage explicitly referring to the events of a particular Caribbean nation?

It refers to the state of things everywhere. The descriptions of life that are conveyed through this character are not limited to the colonial or the postcolonial experience. These are human events, and these are human beings. It is too convenient to wrap up this experience in the term "colonial." The colonial experience only began long after 1492. For a long time there wasn't any settlement; this came only with nineteenth-century British and French settlement. The colonial empire is a nineteenth century phenomenon, and colonialism is a nineteenth-century construction. The unfortunate thing about saying circumstances and events are colonial or non-colonial is that you wrap them up neatly in the term and then lose sight of what really happened. What really occurred was murderous. I have not stepped onto the stage that the terms colonial and postcolonial suggest, because I believe they mask somewhat the fact that the actions and events we are describing are horrifying.

These terms are used too often. Perhaps one should limit their use to descriptions of works of art. In describing everyday actions in parts of the world that have been colonized, it would be more accurate to admit that such actions constitute brutality. We should say that it was brutality that lasted for a certain amount of time, brutality in which a small group of people ruined the lives of one-quarter of the earth's population. We could even say that the beginning of the road to ruining one-quarter of the world's population started with British control of Ireland and continues with the brutality that is ongoing in this country - which is still a colony.

You mentioned in the Cudjoe interview that when you first read Virginia Woolf and James Joyce, you realized that these writers really had "it." Joyce, exiled, experiencing Ireland as a fractured place because of colonialism - had to de- 
velop this kind of aesthetic to represent his particular view of the world. Your response to these writers suggests connections between your work and the modernist tradition.

Before I encountered these writers, I had not read a serious piece of literary fiction written in the twentieth century. I had been used to fiction in which the world had a beginning, middle and end. In this kind of fiction, the world seems to roll along smoothly, to have a moral balance; it suggests that what comes up must come down. It suggests the god-like actions of people bringing order to chaos. This fiction was all very satisfying but not the kind of thing that made me want to write. When I read James Joyce and Virginia Woolf, I discovered the means of putting in writing the experiences I wanted to express. Their writing exposed the world as I saw it: fractured, scattered, and yet somehow whole. I immediately understood modernism. It made incredible sense, because the historical events I write about are also fractured and complicated and antagonistic and ambivalent and contrary. Modernism is more like life than the other kinds of fiction I had read. Ordering the world into a beginning, middle, and end in painting and in literature is what an artist does to stave off the fractured nature of life. But I wanted my writing to be real. I share with Joyce a background of colony. This background is different, of course, but the modernist technique I encountered in his writing seemed to express exactly what I'd hoped to say.

You have said that reading the Brontës was a part of your own schooling. Jean Rhys, of course, responded to Jane Eyre with Wide Sargasso Sea . ${ }^{5}$ Her style also evokes a sense of disorientation.

Some of her books are extraordinary. I think of Rhys and Colette as among essential writers for women. Colette wrote incredibly beautiful, worshipful hymns to her mother. Rhys, especially in her European novels, is very good at expressing the dependency and victimization that is part of the female condition. My characters come from the vanquished and so I consider that they have nowhere else to go but up. In my own life, I am not trapped by my characters' experiences - but I remember their experiences.

In a recent New York Times article, you mention that you "still have the vain idea" that you "aspire to be a great writer." Will you know if you've achieved that status?

I will never know, which is why I keep writing. I want to write until I die, and I hope to live a long time. I don't want to reach a plateau; what I am interested in is living, living. It is possible that I am a great writer right now, but I don't want to know. I don't mind people telling me, but I don't want to know it. I just want to keep writing.

One of the signs of become a great writer may be the attention of academia. There has certainly been a surge in academic interest in your work, and in 


\section{Caribbean writers in general.}

There are two or three books on my work, but I have never read them. I have never read them because I don't really want to know! I'm just as vulnerable as the next person to vanity. I am sure that if they say my writing is wonderful that I would believe it, so I simply don't read them. Whether it includes attention to my work or not, the interest in Caribbean writers is certainly legitimate. All of us - critics and writers - are involved in the enterprise of satisfying curiosity. If there is a body of literature attached to a group of people or area of the world, we should be curious about it. We should want to transfer our curiosity to knowledge through our inquiry.

Some critics imply that academics might be making a potentially re-"colonizing" move by institutionalizing some of the literature emerging from "colonized" places and writers.

This is an example of what I meant when I said people use these words lightly. Colonization is colonization, it concerns peoples and places. People who are interested in this new body of literature are free to try to decide what it means that people from the Caribbean are suddenly putting out so many literary works. It is also noteworthy that most of them are women. But what does it mean to ask? It's not colonization. It's curiosity.

\section{Notes}

${ }^{1}$ Jamaica Kincaid and the Modernist Project: An Interview," Caribbean Women Writers (Wellesley, MA: Calaloux Publications, 1990).

${ }^{2}$ Kincaid writes about her home and gardening as aspects of her own identity in articles such as “The Flowers of Empire," Harper's 292:1751 (Apr. 1996), pp. 28-31; "Plant Parenthood," The New Yorker 71:17 (June 1995), pp. 43-46; "Flowers of Evil" New Yorker 68:30 (Oct. 1995), pp. 154-9; "Homemaking," New Yorker 71:32 (Oct. 1995), pp. 59-64.

3 “An Antiguan Election Journal: March 1994," Clockwatch Review 9:2 (1994-5).

${ }^{4}$ A Small Place (New York: Farrar, Straus, Giroux, 1988).

${ }^{5}$ Wide Sargasso Sea (New York: W.W. Norton, 1982). 